\title{
Peer Tutorial: Championing Students at Risk
}

\author{
Joel B. Tan and Esterlina B. Gevera \\ University of Mindanao \\ Davao City, Philippines \\ https:/ / orcid.org/0000-0002-3902-7986 \\ https://orcid.org/0000-0002-1468-3346
}

\begin{abstract}
This study aimed to evaluate the implementation of the Peer Tutorial Program by the Dynamic Society of Accounting Students (DySAS) of the College of Accounting Education (CAE), University of Mindanao. The study employed descriptive-qualitative research design and focused group discussions were conducted among 21 students selected through purposive sampling. The researchers held all measures to ensure the rigor, trustworthiness, and ethical soundness of this paper. Stories, experiences, and answers of study participants were properly documented, analyzed, and provided with meanings using the thematic analysis approach. Themes on the benefits of Peer Tutorial included: help cultivate good study habits and learning style; improve students' academic performance; reinforce and strengthen personal learning and understanding of topics; build self-confidence and independence in learning accounting and promote progressive education and skills development. The Peer Tutorial Program hopes to bring positive results, joy, hope, and inspiration to students by learning with and through their peers. With the shift to Outcomes-Based Education (OBE), where students are expected to manage their learning styles and pace, the program becomes even more timely and helpful to facilitate the change. Essentially, peer tutorial is a profound expression of commitment to the pedagogy of equitable and conscientious education through collaboration and inclusivity, where students learn and succeed with one another.
\end{abstract}

Keywords: education; peer-learning; tutorial; qualitative; accountancy

\section{Introduction}

Historically, businesses and market enterprises have trusted accountants to provide accurate and timely financial information for informed decisionmaking, to examine the fairness of economic reports, and to assist management in honest compliance with regulatory and tax-reporting requirements (Albrecht \& Sack, 2001). Hence, the demand for accounting graduates has attracted many students to enroll in the accounting program. But the way to becoming an 
accountant is not a walk in the park. It is full of challenges, and only those who remain steadfast until the end survive.

The open admission policy of the University of Mindanao has paved the way for students to enroll in accounting programs regardless of their academic preparedness. However, because of the program's standards and retention requirements, many have failed, dropped, or even shifted to other programs. There had been so many reasons to account why the cohort rate of accounting is judiciously low. First, accounting courses are highly technical and are not that easy to learn. Second, the majority, if not all freshmen, are in the process of personal dissonance and adjustment, a shift from being carefree persons to responsible, mature individuals. Lastly, few students are considerably slow learners; that is, more time and discussions are needed so they could understand the topics substantially.

To address this apparent concern, the College of Accounting Education (CAE) has altruistically designed a peer tutorial program as a mechanism to help students, particularly those 'students at risk, otherwise known as the 'STAR' in acquiring desired competencies and eventually pass the currently enrolled professional courses. The CAE hopes that through academic interventions like tutorials and bridging programs, students will perform better, increase their likelihood to pass the course, and promote the spirit of teamwork among its students, which is one of the core values of the University of Mindanao.

Peer teaching is an old, deep-rooted concept. During Aristotle's time, tutors were played by the archons, or student leaders and were described in the letters of Seneca, the Younger. In 1795, Scotsman Andrew Bell popularized the concept into a theory which then implemented in French and English schools decades after (Briggs, 2013). In principle, peer tutoring is an approach by which one student, known as the expert, instructs another student, called a novice (Briggs, 2013; Dowd, 2018). In recent years, Chen and Liu (2011) and Flores, Veiga Simao, and Carrasco (2012) averred that many Higher Education Institutions (HEIs) around the world had implemented tutoring as an alternative learning system. This is because of the difficulties and inadequacies experienced by students in learning their lessons under a limited, fast-paced class discussion.

Tutorials come in different ways and forms. Briggs (2013) explained the many forms of peer tutoring. One is surrogate teaching that is common in universities and higher learning institutions wherein an older student, often graduate or advanced undergraduate, is given the teaching role for an apprentice or learner. Another kind is proctoring, which is one-on-one tutoring by senior students who have demonstrated expertise with the topic (Bloom, 1984; Briggs, 2014). The emerging type of tutorial is cooperative learning, where a person is given the responsibility to teach others, and each contributes to the group's performance (Johnson \& Johnson, 2009). Alternatively, there is the so-called 'reciprocal peer tutoring (RPT)' where the entire class is divided into pairs to tutor each other. As to ways, it can come in small groups like a mini-seminar or workshop (Exley \& 
Dennick, 2004) or through self-help or tutor-less form (Yazedjian \& Kolkhorst, 2007).

Peer tutorial, as cited by the Athletic Study Center (2016), is an effective learning technique that promotes and enhances the student's academic competencies and self-resolve towards independent learning (Topping, 2005; Colvin \& Ashman, 2010; Viana et al., 2019). In a related study, Chi, Roy, and Hussmann (2008) described peer tutorial as an academic exercise that encourages learners to become active and productive participants in the learning process through interactions with peers. In peer tutorial, tutees and tutors are collaborators of learning. Falchicov (2001) described collaborative learning as instrumental in developing self-esteem, improving classroom engagement, increasing academic interest, and improving study habits (Matine, 2019; Shenoy \& Petersen, 2019). Further, students learning with fellow students eliminate that feeling of intimidation, inhibition, and reservations; thus, making it easy for them to clarify and qualify knowledge without fear of being ridiculed or feeling undignified (Aclo, Damiar \& Norodin, 2015; Dowd, 2018).

In the College of Accounting Education, peer tutorial is a flagship program implemented in partnership with the Dynamic Society of Accounting Students (DySAS), a student organization of the College. One of the fundamental objectives of the program is to provide an avenue for students, especially those who are having a hard time dealing with accounting courses to enhance and improve their knowledge in accounting (Lumactod, Nipales, Pelenio \& Taripe, 2013). The tutorial process begins with the recommendation of the teacher of students (tutees) who failed in at least two assessment periods to join the tutorial program. Tutorial classes are handled by selected DySAS members (tutors) who are competent to deliver the designated topic. To determine whether the program has indeed contributed to the tutee's performance, concerned teachers monitor the progress of the tutee in his or her succeeding assessment periods.

The tutorial program has been in existence since 1991 (Lumactod et al., 2013). Yet, no tangible and substantial studies have been done to gauge how successful the implementation of the program has been relative to its objective of helping students pass their currently enrolled courses, thus helping the College improve its cohort rate. In their latest account, DySAS reported that during the first semester of the school year 2015-2016, they were able to conduct several tutorial sessions for two courses: Accounting 1A and Accounting 5. A total of 122 tutees participated and benefited from the program. Of this number, 95 were Accounting 1A students, and 27 were enrolled in Accounting 5 course. Majority of the tutees enrolled in both courses got a passing mark from 3.5 - 3.1 or $75-79$. Under the Program, tutorial activities include, but not limited to, discussing the scheduled topics, administering and answering pre and posttests, answering problems in the textbook, giving review materials, and presenting an overview of the next topic (Dynamic Society of Accounting Students [DySAS], 2015).

Given the lack of study that assesses the implementation of the Peer Tutorial Program, which could serve as the basis for quality improvement; hence this 
study was undertaken. The researchers believe that this inquiry shall provide concrete evidence on the program's intrinsic value and significance through an objective and comprehensive evaluation of its implementation in terms of delivery and results. Further, this study shall offer practical interventions and recommendations to improve its design, delivery, and overall services. Primarily, this research assesses the level of implementation of the Peer Tutorial Program. Specifically, the study aims to answer the following questions:

1. What is the status of 'STAR' after subscribing to Peer Tutorial?

2. What are the perceptions of 'STAR' on the Peer Tutorial Program?

3. What are the problems encountered by students in the Peer Tutorial Program?

4. How does Peer Tutorial help tutees and tutors in their professional course performance?

5. What are the suggestions of the participants to improve the implementation of the Peer Tutorial Program?

\section{Method}

This section outlines the methodologies and processes employed in the conduct of the study to ensure the integrity and scholarliness of the paper. The discussion is structured in order of the study design, study participants and selection process, phases of exploration, the role of researcher, trustworthiness of the study, and ethical consideration.

\section{Study Design}

The paper utilized a descriptive-qualitative study design. King (2007) mentioned that qualitative studies achieve an in-depth understanding of the 'constructs' people use to describe and rationalize everyday experiences and interactions with the world. We aptly opted for this design as we intended to describe and interpret thoughts and feelings of the participants and find meanings in their shared stories on the implementation of peer tutorial program (Hannes, Booth, Harris \& Noyes, 2013). The qualitative approach is deemed appropriate for this research because it described how the program was implemented and improved the performance of the participants through their experiences and views on peer tutorial, the problems they have encountered as well as their suggestions to enhance the program.

\section{Participants and Selection Process}

The participants of the study were accounting students from the $1^{\text {st }}$ to $4^{\text {th }}$-year level selected through purposive sampling. They were students who had undergone the peer tutorial program at least twice and had given their consent to be part of the study, whether as tutees or tutors. The chosen tutors were outstanding DySAS members, mostly $3^{\text {rd }}$ and $4^{\text {th }}$-year accountancy students who have been involved with the tutorial for at least one (1) year or two (2) semesters. They were shortlisted because of their rich and meaningful experience with the program.

On the other hand, the selected tutees were $1^{\text {st, }}$ and $2^{\text {nd-year }}$ accountancy and accounting technology students who have shown consistent poor academic performance, sedentary class participation and are considered 'at risk' of failing 
the course. They were referred and nominated by their accounting teachers. However, to qualify as participants, they must have attended the tutorial session at least twice, are willing to participate in the study, and are confident about the impact of the program in their academic success. The participants were clustered into three (3) of seven (7) participants (Creswell, 1998), namely: the tutors, the triumphant tutees, and the fruitless tutees.

\section{Phases of Exploration}

Data were gathered through document analysis and focus group discussions (FGDs) using an expert-validated interview guide during the $3^{\text {rd }}$ quarter of the academic year 2016-2017. The format of the FGD was open and spontaneous to reduce inhibitions among participants. While the interview was structured around predetermined questions, the discussion went interactive, free-flowing, and dynamic. Marshall and Rossman (as cited in Walby, 2015) suggested that the data collection method in qualitative research is categorized into four types: participation in the setting, direct observation, in-depth interview, and document analysis. The responses during the FGD were carefully logged using notes and a machine recorder, accurately transcribed and confirmed by the participants in a journal. Data gathered were coded individually and categorized based on the nature of participation as either tutee (TE) or tutor (TR) and research objectives. After then, the coded data were analyzed using the thematic analysis approach.

\section{Role of Researchers}

As researchers, we played the following roles in the study. One of the roles we played was as interviewers. As such, we captured and document stories of our participants relevant to the study objectives. As interviewers, we made sure that a carefree and relaxed conversation is carried on the set. With a sincere yet light environment, we allowed our participants to share their experiences without intimidation, pressure, and fear of being judged. Another important role we assumed was as observers. Since this inquiry is qualitative, we were equally interested in non-verbal languages like emotions and mannerisms as with their words. We believe that often, meaningful anecdotes can be drawn from unguarded facial expressions, behaviors, and gestures. For this purpose, we kept an eye-to-eye contact with our participants during the interview.

In addition, we also took the role of encoders. The first thing we encoded was the accounting performance of our participants before and after they have joined the tutorial program. This coding was needed to determine the statistical impact of peer tutorial to the tutees' academic progress. After this, we carefully recorded the participants' responses during the interview. The narratives of the participants are critical to validate the numbers collected. As encoders, we observed honesty and impartiality to ensure that the themes and concepts generated are according to the context and perspective of our participants. To this end, we employed the audit trail to facilitate an easy and efficient way to indexing the responses of our participants to and from the transcripts of focus group discussion. The format we used was (TE-P\#/TR-P\#). TE stands for the 'Tutee' while TR represents 'Tutor.' The P\# means' Participant Number'. Say, for 
example (TE-P1), interpreted as Tutee - Participant 1 or (TR-P1), described as Tutor - Participant 1.

\section{Trustworthiness of the Study}

In qualitative studies, the trustworthiness of the study is both paramount and sacred. This thrust is ensured by keeping high levels of integrity, transparency, and objectivity in the collection, transcription, and interpretation of data. In his literature, Shenton (2004) indicated four elements of reliability to include credibility, transferability, dependability, and confirmability. As with credibility, the study was carried out systematically (Silverman, 2015; Shenton, 2004). We followed technical and ethical standards in the collection and analysis of data. Processes and tools were checked, reviewed, and verified by experts in qualitative studies. Conversely, transferability was upheld through clear-cut research objectives, contextualized themes, and well-defined respondents. Moreover, we never allowed our personal biases and prejudices to influence the outcome of this study (Creswell, 1998; Shenton, 2004).

Similarly, to ensure dependability, member checking was done on the data before and after analysis and interpretation. Participants were able to validate their narratives as to completeness and accuracy (Silverman, 2015). Further, participants were adequately oriented on the purpose and rigor of the study, especially on data gathering. Lastly, confirmability was secured in this study through the use of audit trails. This device allows the reader to trace and confirm the information from its raw source. Marshall and Rossman (2010) stressed that the findings, interpretations, and conclusions must be supported appropriately. Besides, all materials and instruments used in this study were kept intact for verification and corroboration purposes.

\section{Ethical Consideration}

As researchers, we put high regard to the anonymity of our participants and the confidentiality of the data gathered. On this, pseudonyms were assigned to the participants to hide their identity. The information gathered was never shared with others and used other than the purpose of the study. Consent was also secured to guarantee the voluntary participation of the participants. We respected the right of our participants to withdraw from participating should they decide to discontinue. Further, this research paper is entirely credible, devoid of any data manipulation, deceit, and plagiarism.

\section{Results}

This section of the paper presents the results of the data gathered. It outlines the meaningful and significant answers of the participants to questions relevant to the objectives of the study. The results are presented following the order of the research questions.

\section{Status of "STAR" after subscribing to Peer Tutorial}

We began our exploration of the phenomenon by looking at the summative report of the tutorial program prepared by DySAS for the $1^{\text {st }}$ semester of 20152016. A total of 122 students attended the program for the entire semester, with an overall passing mean rating of 65.81 percent. Accounting $1 \mathrm{~A}$ recorded 56 
passers with a general passing rate of 61.54 percent, 35 flunkers, and four no grade or in dropped condition. Meanwhile, 21 tutees enrolled in Accounting 5 passed the course with a staggering 80.77 percent passing percentage, with five flunkers and one no grade or in dropped status. While we were confident that the program had helped our STARs, we did not discount the fact that there might be students who failed to profit from the program.

Table 1: Report on Peer Tutorial Implementation

\begin{tabular}{|c|l|c|c|c|c|c|}
\hline Period & Subject & Passed & Failed & $\begin{array}{c}\text { No Grade (NG) } \\
\text { and Dropped }\end{array}$ & Total & $\begin{array}{c}\text { Passing } \\
\text { Rate }\end{array}$ \\
\hline \multirow{2}{*}{\begin{tabular}{c}
$1^{\text {st }}$ semester \\
\cline { 2 - 7 }
\end{tabular}} & Accounting 1a & 56 & 35 & 4 & 95 & $61.54 \%$ \\
\cline { 2 - 7 } & Accounting 5 & 21 & 5 & 1 & 27 & $80.77 \%$ \\
\cline { 2 - 8 } & Overall & 77 & 40 & 5 & 122 & $65.81 \%$ \\
\hline
\end{tabular}

As shown in Table 1, the tutorial sessions in Accounting 1A and Accounting 5 helped the STARs pass their currently enrolled courses. In the study of Braganza, Capisnon, Dela Salde, and Manib (2014), peer tutorials increase the level of performance of students in an exam. It is worth noting, though, that some tutees failed to proceed because of irregular attendance and poor participation during the session.

In the related study, Briggs (2013) noted that those who obtained higher scores on the QRI (Quality Reading Inventory) test are students engaged in peer learning. This suggests the positive effect peer tutoring can have on academic performance. While academic achievement is a function of many factors, including aptitude, preparation, and environmental support, a tutorial session is a big rally round to nurturing and strengthening the readiness and confidence of students to do good in class and eventually pass the course.

Table 2: Perceptions on Peer Tutorial Program

\begin{tabular}{|c|c|c|}
\hline $\begin{array}{c}\text { Core } \\
\text { Ideas/Themes }\end{array}$ & $\begin{array}{c}\text { Frequency of } \\
\text { Responses }\end{array}$ & Key Statements \\
\hline A review session & Typical & $\begin{array}{c}\text { "Attending tutorial sessions enables students to } \\
\text { review their accounting lessons by answering the } \\
\text { pre and posttests" - (TR-P1) }\end{array}$ \\
\hline $\begin{array}{c}\text { Platform to share } \\
\text { knowledge and } \\
\text { learn with others }\end{array}$ & General & $\begin{array}{c}\text { "I always had fun. You get to share and learn } \\
\text { new knowledge with fellow students" - (TE-P10) }\end{array}$ \\
\hline $\begin{array}{c}\text { Create } \\
\text { acquaintances and } \\
\text { friends }\end{array}$ & Typical & $\begin{array}{c}\text { "Tutorial was fun. I can meet different people } \\
\text { and find friends" - (TE-P15) }\end{array}$ \\
\hline $\begin{array}{c}\text { Stressful and } \\
\text { challenging }\end{array}$ & Typical & $\begin{array}{c}\text { "When tutees find the topic very hard to } \\
\text { understand even if repeatedly taught" -(TE-P7) }\end{array}$ \\
\hline $\begin{array}{c}\text { Interactive and fun } \\
\text { learning } \\
\text { experience }\end{array}$ & Typical & $\begin{array}{c}\text { "We were provided with discussions about a } \\
\text { topic. We were encouraged and allowed to ask } \\
\text { questions freely. We were provided with sample } \\
\text { problems with answers. It is a great experience" - } \\
\text { (TE-P12) }\end{array}$ \\
\hline
\end{tabular}




\begin{tabular}{|c|c|c|}
\hline $\begin{array}{c}\text { Reinforce } \\
\text { classroom learning }\end{array}$ & General & $\begin{array}{c}\text { "Allow us to learn through various methods and } \\
\text { activities like pre and posttest, seatwork, oral } \\
\text { recitations, reporting, working with buddies and } \\
\text { giving assignment" - (TR-P1) }\end{array}$ \\
\hline $\begin{array}{c}\text { Discover new } \\
\text { learning not taught } \\
\text { in the classroom }\end{array}$ & General & $\begin{array}{c}\text { "It adds new learning because they also teach } \\
\text { things not discussed in the class" -(TE-P17) }\end{array}$ \\
\hline $\begin{array}{c}\text { Find models and } \\
\text { inspiration to do } \\
\text { better in studies } \\
\text { and in life }\end{array}$ & Typical & $\begin{array}{c}\text { "I have become more patient in studying and } \\
\text { developed new ways to learn better and faster" - } \\
\text { (TE-11) }\end{array}$ \\
\hline $\begin{array}{c}\text { Builds teamwork } \\
\text { and sense of } \\
\text { responsibility to } \\
\text { learning }\end{array}$ & Typical & $\begin{array}{c}\text { "I really make sure that I will be present when I } \\
\text { am assigned to teach or tutor. This makes me } \\
\text { more responsible and caring of others" - (TR-P7) }\end{array}$ \\
\hline $\begin{array}{c}\text { Boring, } \\
\text { unorganized, and } \\
\text { non-interactive }\end{array}$ & Variant & $\begin{array}{c}\text { "When we have to move from one room to } \\
\text { another and when the tutorial session seems } \\
\text { unprepared and unorganized" -(TE-P8) }\end{array}$ \\
\hline
\end{tabular}

Having stern interest and strong desire in one thing will drive every person to commit, pursue, and work hard for it. This interest is influenced by a person's need, condition, priorities, and perception. This truth led us to ask our participants about their views and thoughts about the tutorial program. We probed this area first to be able to understand the students' reasons for attending or withdrawing from the activity. We carefully captured and classified the answers of our participants based on their universal thesis. The following ten themes emerged from the responses on the perceptions on the Peer Tutorial Program.

\section{A Review Session}

A tutorial session simulates a typical review class where tutors and tutees update and refresh themselves on specific accounting topics. The tutors who are assigned to manage the learning session had to review themselves and master the topics to be discussed so they can deliver satisfactorily to the tutees (TR-P1). The tutees, on the other hand, had to appraise themselves of what they have already learned so they can catch up with the lesson (TE-P11; TE-P13). Tutors also employ various teaching techniques characterizing a typical teachinglearning environment. Participant (Tutor) 1 aptly said,

"Attending tutorial sessions will enable students to review their accounting lessons by answering the posttest and pre-test prepared by the tutor" - (TR-P1)

This is supported by Participant (Tutee) 13 saying,

"It helped me retain the topics I have studied in the past" - (TE-P13)

Essentially, akin to review class, tutors provide learning materials, discuss the outlined topics, and conduct assessment activities. 


\section{Platform to share knowledge and learn with others}

CAE's tutorial program is a student initiative. It is run and managed by DySAS, an organization of accounting students. The program allows selected members, usually academic scholars and accounting-adept students, to become tutors to share their knowledge and skills to their fellow students, especially those who are at risk and those belonging to lower years. The entire process espouses the sharing of knowledge among fellow students and learning along with others, not just about accounting but also about best practices on how to manage time, stress, and personal issues (TR-P3; TR-P6; TE-P11; TE-P18). Participant (Tutor) 3 profoundly recounted,

"It is very fulfilling on my part because I can be able to share what I have learned in accounting. Also, I have the opportunity to share my study habits to them" - (TR-P3)

Participant (Tutee) 18 echoed,

"Of course, I am happy being able to learn with my classmates and friends as we share ideas" - (TE-P18)

Over time, the program has transcended from sheer teaching to coaching, mentoring, and advising. It has empowered tutees to be self-reliant and to interact confidently with their fellow tutees, friends, and classmates. In effect, the breadth of learning from simple tutorial sessions has become even more extensive and more impactful.

\section{Creating acquaintances and friends}

Apart from the opportunity to learn, the tutorial program is also a venue to win friends and comrades. Learning together fosters good rapport and friendship between and among tutors and tutees (TR-P1; TR-P3; TR-P7; TE-P11; TE-P19). This makes learning even more enjoyable and exciting. Participant 7 (Tutor) and 11 (Tutee) declared,

"The tutorial experience was great. I was able to make friends with tutees" - (TR-P7)

"Tutees and tutors become friends" - (TE-P11)

Sharing knowledge and interacting with one another is a show of care, building mutual trust and respect, which are essential elements to creating and keeping relationships such as friendship. After all, learning, to be extra meaningful and exciting, must be fun and shared with friends.

\section{Stressful and challenging}

A tutorial session can be toxic and exhausting both for student tutors and tutees. Both tutors and tutees have to manage their time to prepare and attend to the tutorial sessions (TR-P1; TR-P2; TE-P8). Tutors, in particular, have to bear the difficulties of reviewing and strategizing on how the topics will be discussed. They even have to bear tutees' diverse personalities, motivation, priorities, concerns, and reception towards the session, not to mention the feeling of anxiety during the discussion and in answering every tutee's question. Participant 1 (Tutor) cordially narrated, 
"The challenging moment for me is seeing tutees not prepared coming to the session and not doing their assignment" - (TR-P1)

Even Participant 5 revealed one of her sad experiences by telling us,

"There was once an instance when my tutee asked a question, and I was not able to answer it. I felt embarrassed and disappointed at myself" (TR-P5)

For tutees, it has always been a challenge to review past lessons or learning new ones in a fast-paced manner. More so, the time available for the tutees that could match the tutors' free schedule as regular classes are continuing.

\section{Interactive and fun learning experience}

Nothing beats fun learning. It does not only fight boredom and exhaustion, but it also increases topic absorption and retention. The tutorial works through interactive and fun learning activities (TR-P2; TE-P8; TE-P10; TE-P12; TE-P19). With interactive and fun learning activities, tutees are expelled from feeling bored, exhausted, and mentally-consumed. Instead, they remain to be attentive, focused, and alive during the entire session. Participant 2 shared,

"I had great interactions with my tutees. It is fun to learn accounting on tutorials" - (TR-P2)

Participant 8 disclosed,

"I had good times with the tutorial session when the discussion happens to be interactive, and all my questions are answered" - (TE-P8)

Participant 10 warmly disclosed,

"I always had fun. You get to share and learn new knowledge. I had fun reviewing" - (TE-P10)

Tutors are not just predisposed to do lecturing as a means to discuss the topics but also tasked to use other approaches like cooperative learning and studentled discussions that encourage independent-learning, interaction, and active participation. These approaches to teaching also help the tutors save their energy and tone by shifting their role from being a resource person to a facilitator and, at the same time, addressing the multi-intelligences and varied learning styles of students.

\section{Reinforces classroom learning}

The tutorial session is designed to reinforce class discussion of identified topics that are critical and challenging to students, especially for those at risk of failing or have shown poor academic performance consistently. The tutorial aims to strengthen student understanding of accounting topics learned first inside the classroom (TE-P10; TE-P11; TE-P13; TE-P15; TE-P16; TE-P17). Participants 15 and 16 convincingly recounted,

"Tutorial session is very helpful to us. It helps us clear lessons we do not understand" - (TE-P15) 
Through the review materials provided and discussions given, students are able to deepen their understanding of the topic. They are even encouraged to ask questions or clarify information which they have missed to ask or are afraid to clarify with their teachers (TE-P11; TE-P12; TE-P13; TE-P14; TE-P17). Participant 12 narrated,

"We were provided with discussions about a particular topic. We were encouraged and allowed to ask questions freely without feeling intimidated by the tutors. We were provided with sample problems with answers. It is a great experience"- (TE-P12)

Indeed, the tutorial session can be a potent mechanism to enhance the learning and comprehension of the students, especially those who struggle and have difficulty in understanding and learning the lessons at once. In the tutorial, the pacing is relatively slow as the topic discussions are specific and controlled. It can also be an excellent aid for students who have missed their classes as they can learn the topics they missed during the tutorial. Participant 3 confidently said,

"I learned new topics from the session" (TE-P3)

While tutorials are held to reinforce learning which occurred inside the class, being attentive and engaged during classroom encounters with teacher remains to be very important and will help a lot in improving our academic performance.

\section{Discover new learning not taught in the classroom}

In some rare cases and circumstances, the tutorial session becomes a hub of new knowledge and accounting skills. Tutors share techniques in solving accounting problems and tips in understanding difficult concepts and principles. Apart from accounting, tutees also learn from their tutors best practices on how to manage time, how to study effectively, and how to learn steadfastly. Time and again, it has been acknowledged that education goes beyond the classroom; tutorial sessions can be a ground of fresh, meaningful experiences and instruction helpful to understanding accounting and even life, in general. Participant 12 noted,

"Tutorials provide me with new tips, techniques, and shortcuts in understanding and solving problems" - (TE-P12)

We categorically believe that learning is not confined within the four walls of the classroom. There are discoveries and fresh thoughts that take place beyond it and which are, in several instances, more meaningful and exciting as these were acquired spontaneously and with others.

\section{Find models and inspiration to do better in studies and in life}

The tutorial session is more than just learning with experts. It is also an opportunity where tutors model and inspire student leadership and excellence to tutees. One apparent impact of the tutorial is that tutees find exemplars and inspiration from the tutors. Tutees see their tutors as their motivation to do better and be like them. This idea was shared by Participant 20 pronouncing,

"I study more now than before because I am inspired by the advice of our tutor" - (TE-P20) 
The admiration and respect developed by tutees towards their tutors can lead to emulation and replication; thus, tutors become persons that tutees look up to as their model of scholarship, responsibility, and resilience. In many circumstances, tutors also provide peer advising relating to career goals and personal issues. One of the tutors, our Participant 3 delightfully narrated,

"One of the happy moments I've had with the tutorial session was when

I inspired students not only to work hard for accounting but also to learn to love it" - (TR-P3)

In tutorial sessions, students do not only acquire and enhance their knowledge and understanding of a specific topic and make new friends but also find exemplars that serve as inspiration and models of motivation.

\section{Builds teamwork and sense of responsibility to learning}

The success of tutorials rests on the teamwork and commitment between and among tutors and tutees. Tutors need to demonstrate teamwork by planning the details of the tutorial session to include the list of topics, the assignment of tutors, and the flow of the session. Consequently, tutees must show commitment and support through active participation and engagement during the session. A tutorial is not about the tutors or the tutees individually; it's about the collaboration forged between the two and the shared responsibility towards learning. In the equation of tutorial, teamwork and shared responsibility are the essential variables. Heartwarming insights we heard from our participants was from Participants 5 and 12 when they realized,

"It made me realized that dealing with accounting, you need a friend to walk with you on the journey. The best buddy you could have is your peer" - (TR-P5)

"The feeling of accomplishment was indescribable. Learning with peers is a good thing, especially when everyone is attentive and cooperative. It made me easy to understand the topic" - (TE-P12)

Learning with others through the tutors or mentors or coaches is an experience that beholds teamwork, responsibility, charity, and sharing. These same qualities are what the University of Mindanao wants from its students and graduates.

\section{Boring, unorganized and non-interactive}

One common reason why students are not attracted to tutorials and likely to withdraw and disengaged during sessions is because of its predisposition to get boring and non-interactive. This situation typically happens when tutors failed to meet the interest and expectations of the tutees; when learning materials are lacking; teaching strategies are repetitive; tutors are unprepared, and the environment is not conducive for learning. Participant 8 shared,

"When we have to move from one room to another and when the tutorial session seems unprepared and unorganized" - (TE-P8)

Just like any other learning session, be it a formal class or a tutorial, making the session attractive to students and sustaining its dynamics and energy is a 
continuous challenge. Hence, while tutors may have the key responsibility to design and navigate the session, tutees have equal power to make it enjoyable and productive.

Table 3: Problems Encountered by "STAR" on Peer Tutorial

\begin{tabular}{|c|c|c|}
\hline Core Ideas/Themes & $\begin{array}{l}\text { Frequency of } \\
\text { Responses }\end{array}$ & Key Statements \\
\hline $\begin{array}{l}\text { Difficulty of scheduling the } \\
\text { date and time of tutorial }\end{array}$ & General & $\begin{array}{l}\text { "Most of the time, the schedule of tutorial } \\
\text { is in conflict with our classes and } \\
\text { personal schedules" -(TR-P1) }\end{array}$ \\
\hline $\begin{array}{l}\text { Tutors' lack of skills in } \\
\text { tutoring and of teaching } \\
\text { strategies }\end{array}$ & Variant & $\begin{array}{l}\text { "Some tutees are bored because of the } \\
\text { lack of teaching skills of the tutors" - } \\
\text { (TR-P4) }\end{array}$ \\
\hline Lack of tutorial room & General & $\begin{array}{l}\text { "We have to look for a vacant room every } \\
\text { time we hold the tutorial; otherwise we } \\
\text { have to disrupt or cancel the activity" - } \\
\text { (TR-P5) }\end{array}$ \\
\hline $\begin{array}{l}\text { Lack of learning materials } \\
\text { and resources }\end{array}$ & Typical & $\begin{array}{l}\text { "There were times when materials and } \\
\text { topic notes were not provided which } \\
\text { could be very helpful so we can follow } \\
\text { the discussion and have it reviewed at } \\
\text { home" -(TE-P13) }\end{array}$ \\
\hline $\begin{array}{l}\text { Lack of teachers' } \\
\text { encouragement and } \\
\text { support }\end{array}$ & Variant & $\begin{array}{l}\text { "There could be more tutees in } \\
\text { attendance if teachers would require } \\
\text { those who are supposed to attend. And } \\
\text { there should be credit points to be given } \\
\text { to tutees" -(TR-P6) }\end{array}$ \\
\hline $\begin{array}{l}\text { Unsound attitude of Tutees } \\
\text { and Tutors }\end{array}$ & Variant & $\begin{array}{l}\text { "Students attending the tutorial sessions } \\
\text { are eager to learn, but as the discussion } \\
\text { goes on, they get bored easily and slowly } \\
\text { losing focus" - (TE-P10) }\end{array}$ \\
\hline
\end{tabular}

As with any other initiatives, activities, and programs, the tutorial has its own set of problems and challenges that can derail the achievement of its goals and objectives. We thought that the tutorial might not be perfect, hence need to improve continually. There may be errors, weaknesses, and limitations in its method and mechanism that need to be addressed. Having said so, we, researchers explored the problems and challenges as perceived and experienced by the participants. The six themes that emerged from the anecdotes on the problems encountered by "STAR" on Peer Tutorial Program are provided herewith.

\section{Difficulty of scheduling the date and time of tutorial}

Tutors and DySAS officers agreed that one of their pressing problems in the conduct of tutorials was to sync the schedule of the tutor and the tutees. Participants confessed that organizing a peer tutoring activity can be daunting and challenging, even during scheduling. There must be a common, agreedupon time structure for the tutorial session that will not compromise regular classes of both tutors and tutees. Failure to meet both parties' availability would mean no tutorial session. Time must be open, free, and unrestricted to allow comprehensive, complete, and concentrated discussions. 
Typically, tutorial sessions are done on weekdays, during the free hours of the tutees and tutors. While this is relatively difficult because students have reservations to participate owing to the regular classes that they have to attend to in-between or after the session, weekend schedules are nearly impossible either because of the many, equally important activities that both tutors and tutees have to accommodate like the bridging program, OJT seminars, weekend exams, thesis defense, CWTS, and PE classes among others. Participant 1 captured this challenge saying,

"Most of the time, the schedule of the tutorial is in conflict with class and personal schedules" - (TR-P1)

Another concern was revealed to us by Participant 12 citing,

"I hope tutorial sessions do not fall on regular class schedule so that they will not be in conflict with regular class" - (TE-P12)

Having the right schedule that allows students-at-risk to be in attendance can make the program more efficient and valuable to those who especially need it. This is something DySAS has to manage and deal with effectively.

\section{Tutors' lack of skills in tutoring and of teaching strategies}

One critical element that could make or break a tutorial session is the knowledge, skills, and attitude of the tutors. Many agreed that one major culprit to a successful tutorial is the lack of competency among tutors in imparting knowledge and managing the session. Without the right attitude and skills, the discussion tends to become unorganized, boring, and ineffective. Tutees, when feeling bored and worn-out, easily lose their focus, become disengaged, and can be unreceptive towards learning.

While tutors must be knowledgeable on the subject and topics they ought to share with the tutees, they must also be equipped with the appropriate tutoring/teaching skills in order to transfer such knowledge effectively. Tutors must be well-armed with excellent communication and interpersonal skills alongside the values of passion, commitment, patience, and understanding. A participant narrated,

"Tutors' way of teaching must be lively, and tutors must have a sense of humor to break the monotony of discussion and catch our attention - the tutees" - (TE-P11)

This challenge was also recognized among tutors. One tutor confessed, "We should have seminars and training to help us improve our teaching skills" - (TR-P6)

Apart from the technical knowledge, there is also a need for tutors to become adept at various teaching approaches and pedagogy to become effective and relevant in their instruction. 


\section{Lack of tutorial room}

One of the most important logistical requirements for the conduct of tutorials is a room- a place conducive for learning. The room must be spacious, well-lighted, with good ventilation and physical resources like chairs, tables, and whiteboards. Ideally, a tutorial room must support a productive and fun learning experience.

Apart from managing an amenable schedule that works for tutors and tutees, another perennial concern that besets DySAS every time tutorials are planned is where to hold the learning sessions. By practice, tutorials are held in vacant classrooms and discussion rooms at the library. However, it must be prescheduled since reservations are also limited. This problem was best articulated through suggestions by Participants 5 and 12 citing respectively,

"There must be a permanent room that is conducive for learning" (TR-P4)

"The College must also provide vacant rooms specifically intended for the conduct of tutorial because as experienced, we do not have permanent rooms which led to the interruption and cancellation of the session" - (TE-P12)

As members of the faculty of the CAE, we remembered that there was a time where no rooms are available; thus, tutees and tutors just hopped from one classroom to another every after an hour, which disrupts the energy, concentration, and learning momentum of the participants. This kind of experience discourages students from actively attending the activity.

\section{Lack of learning materials and resources}

Learning is never perfected within the tutorial session. The quality of tutoring is affected by many limitations, including the time, the environment, and the type of tutees in attendance, hence to augment student learning, materials and resources are indispensable. However, these things are inadequate, if not completely lacking among tutors. Given this scantiness, it could impede the learner's capacity to fully grasp the concepts and topics taught during the residential session. Having no materials at hand may also trigger disengagement and demotivation among tutees.

As tutees have different styles and ways of learning, different pacing, and conditions during the session, the learning materials could greatly help reinforce the topics discussed. It can also facilitate better learning as the tutees do not just hear the discussion but also have something to see and follow-through, especially for visual learners. Alternatively, tutees need materials so they can relearn and practice their learning at home, in the classroom, or at the library, thus deepen and enhance their understanding of the topic. This problem was shared vividly to us by Participant 15 saying,

"Tutors must provide learning materials like sample questionnaires and reviewers that we can bring at home for further study and practice" (TE-P15) 
With the learning materials available on hand, tutees will become independent learners themselves, that is, self-directed learning, away from the oversight of tutors and only through the aid of adequate and appropriate materials. This is an autonomous learning that works.

\section{Lack of teachers' encouragement and support}

As an intervention program for the STARs (students at risk), the process design of tutorial is cyclical; and it begins from the inputs of the teachers. It is the task of the teachers to identify students who need help and intervention, especially those who have shown consistent poor performance in the class and on examinations. They must encourage students to attend tutorials. This idea was resonated strongly by Participant 2 when she told us,

"Teachers must require their students to attend tutorial classes especially those who need peer tutorial" - (TR-P2)

Likewise, teachers need to monitor the progress of their students. They should help evaluate the effectiveness of the program through reinforcement in the classroom, like giving out assessment tasks related to the topics discussed during the session. To encourage participation, teachers may include in their quizzes and even in the exam problems given during the tutorials. Through this, students can find connection, value, and appreciation of the program. On this note, Participant 6 commented,

"There should be an evaluation of the performances of tutees inside the classroom" - (TR-P6)

From a different perspective, Participant 4 mentioned another role accounting teachers have to play in improving the implementation of the program. He loudly pondered,

"I think there must be a professor or any equivalent representative of the

College to evaluate the performances of the tutors" - (TE-P4)

With how the program works, the roles of teachers as providers of inputs and evaluators of outcomes are critical. Teachers' constructive feedback on the program delivery and outcomes will serve as valuable inputs to the quality improvement program of the College. The worst that could happen is when teachers failed to monitor whether tutors are doing what they are supposed to do and that tutees are making progress in their performance.

\section{Unsound attitude of Tutees and Tutors}

We believe that beyond the legitimate issues of lack of resources and support system, the low turnout and poor participation among tutees and even tutors are influenced by their attitude and impression towards the program.

One significant factor that contributes to the success of any program, such as tutorials, is the attitude of the tutees. When tutees come to tutorial sessions just to comply with their teacher's encouragement or requirement, they remain passive and disengaged with the activity. When tutees view tutorial sessions as burdensome, insignificant, and ineffective, they become reluctant and will most likely not attend or become apathetic to the program. When tutees find no 
appreciation and remain unsympathetic towards the tutors and the learning activities, the quality of learning is compromised. This iniquitous truth was framed in the words of Participant 11 when she recounted,

"As tutee, tutorial session does not have any impact on my academic performance because I am satisfied with my professor's performance. There is no reason for me to attend tutorial session" - (TE-P11)

Participant 14 echoed,

"During tutorials, while the tutors are friendly and approachable, but what they are teaching is just the same with what we're given in the class. The knowledge I have gained inside the classroom is just the same as in the tutorials" - (TE-P14)

As with tutors, when they see the program as an obligation than a noble responsibility, they will easily succumb to indolence and apathy, making their performance less satisfactory and mediocre. When tutors perceive tutorials as onerous and unrewarding, they may stop learning and enhancing their skills and eventually stay-off from the program. Indeed, the attitude and commitment of both tutees and tutors matter in the value proposition of tutorials.

Table 4: Benefits of Peer Tutorial to "STAR" and the Tutors

\begin{tabular}{|c|c|c|}
\hline Core Ideas/ Themes & $\begin{array}{l}\text { Frequency of } \\
\text { Responses }\end{array}$ & Key Statements \\
\hline $\begin{array}{l}\text { Help cultivate good study } \\
\text { habit and learning style }\end{array}$ & General & $\begin{array}{l}\text { "For me, it improves my study habit } \\
\text { especially on taking down notes and how } \\
\text { to become focused in everything that you } \\
\text { do" -(TE-P16) }\end{array}$ \\
\hline $\begin{array}{c}\text { Improve students' } \\
\text { academic performance }\end{array}$ & Typical & $\begin{array}{l}\text { "My classroom performance like my } \\
\text { quizzes and exam scores has improved } \\
\text { because I can relate the questions from } \\
\text { the tutorial" -(TE-P15) }\end{array}$ \\
\hline $\begin{array}{l}\text { Reinforce and strengthen } \\
\text { own learning and } \\
\text { understanding of topics }\end{array}$ & General & $\begin{array}{l}\text { "Tutorial session really helps students } \\
\text { because tutors can share some topics that } \\
\text { were not taken up in classes" -(TE-P13) }\end{array}$ \\
\hline $\begin{array}{l}\text { Build self-confidence and } \\
\text { independence }\end{array}$ & Typical & $\begin{array}{l}\text { "Attendance to tutorial improved my } \\
\text { competence and confidence in } \\
\text { understanding accounting. It pressured } \\
\text { me to strive more and learn more } \\
\text { accounting courses." -(TE-P12) }\end{array}$ \\
\hline $\begin{array}{l}\text { Promote active education } \\
\text { and skills development }\end{array}$ & Typical & $\begin{array}{c}\text { "After attending tutorials, I am just } \\
\text { studying on my own. I can really answer } \\
\text { questions" -(TE-P15) }\end{array}$ \\
\hline
\end{tabular}

At this point, we have explored the real and perceived benefits of the program for both tutees and tutors alike. Understandably, what attracts and keeps the participants from being engaged and committed are the favors and gains they get from it. While there are participant-centered objectives outlined in the program, these can only make sense when achieved satisfactorily and have impacted the participants significantly. Five themes have emerged describing the benefits of the program, to wit: 


\section{Help cultivate good study habit and learning style}

Students believed that the tutorial has helped them cultivate good study habits and learning styles. Tutees confessed that their study hours have increased after joining the learning sessions. Moreover, tutees were able to develop the right attitude, competencies, and disposition towards learning after consistent participation. Participant 16 recounted,

"For me, it improves my study habit especially on taking down notes and how to become focused in everything that you do" -(TE-P16)

\section{Improve students' academic performance}

The tutorial strengthens learning motivation and increases students' academic accomplishments. Tutees attributed the improvements in their class performance to their active participation in tutorials. Results of both formative and summative assessments, like quizzes and exams, have improved. In addition, tutees have shown improvements in their attitude towards learning. In fact, Participant 15 shared,

"My classroom performance like my quizzes and exam scores has improved because I can relate the questions from the tutorial" -(TEP15)

\section{Reinforce and strengthen own learning and understanding of topics}

Tutors reinforce their learning through tutoring. By instructing their peers, tutors even enrich their knowledge and develop their sense of compassion and responsibility for others. Tutors become more competent in the topic and diligent in their studies as they have to ensure their tutees will learn and get inspired through them. As tutors, they need to retool themselves and master the knowledge they ought to impart. In the words of Participant 13, she said;

"Tutorial session really helps students because tutors can share some topics that were not taken up in classes" -(TE-P13)

\section{Build self-confidence and independence}

Peer tutorial is a confidence booster. Studying with someone of relatively the same age typically makes students feel more comfortable and relaxed. They do not feel as intimidated with a peer as they might with a teacher. Besides, peer tutors can share personal struggles with the subject material, such as rationalizing the difficulties they have encountered and what strategies they used to overcome it. This circumstance allows the learner to feel comforted and empowered. On this note, Participant 12 narrated,

"Attendance to tutorial improved my competence and confidence in understanding accounting. It pressured me to strive more and learn more accounting courses." -(TE-P12)

\section{Promote active education and skills development}

Direct peer tutoring promotes active learning and skills development. Peer teaching-learning provides opportunities for students to raise questions, confer issues, exchange viewpoints, and engage in collaborative learning by working in teams on problems and tasks. The use of varied and effective teaching strategies like role-plays, healthy discourses, case studies, and simulated projects not only 
stir students' enthusiasm and creative participation but also address their multiintelligences. Confidently, Participant 15 told us,

"After attending tutorials, I am just studying on my own. I can really answer questions" -(TE-P15)

\section{Suggestions to Improve the Implementation of the Peer Tutorial}

This section presents the suggestions of our participants to improve the design and delivery of the tutorial program through an action plan. The six themes that emerged from the suggestions of the participants on how to improve the implementation of the program, both the design and execution, are provided in table 5 .

Table 5: Suggestions to Improve the Implementation of the Peer Tutorial

\begin{tabular}{|c|c|c|}
\hline $\begin{array}{c}\text { Core Ideas/ Themes } \\
\text { campaign about the } \\
\text { program }\end{array}$ & Frequency of Responses & Key Statements \\
\hline $\begin{array}{c}\text { Conduct a college-wide } \\
\text { and resources }\end{array}$ & Typical & $\begin{array}{c}\text { "The College should } \\
\text { promote the program so that } \\
\text { many students would be } \\
\text { aware of it and can } \\
\text { participate" - (TR-P3) }\end{array}$ \\
\hline $\begin{array}{c}\text { Offer a flexible schedule or } \\
\text { tutorial-time option }\end{array}$ & General & $\begin{array}{c}\text { "Provide learning materials } \\
\text { like sample questionnaires } \\
\text { and reviewers" -(TE-P15) }\end{array}$ \\
$\begin{array}{c}\text { Conduct one-on-one } \\
\text { tutorial sessions }\end{array}$ & $\begin{array}{c}\text { "Posting of flexible } \\
\text { schedules for the tutorial } \\
\text { session should be made } \\
\text { clearly and ahead of time" - } \\
\text { (TE-P10) }\end{array}$ \\
\hline $\begin{array}{c}\text { Provide a tutorial facility } \\
\text { or room }\end{array}$ & Variant & $\begin{array}{c}\text { "There must be one-on-one } \\
\text { tutorial session or buddy- } \\
\text { buddy system especially for } \\
\text { working students" -(TE-P11) }\end{array}$ \\
& General & $\begin{array}{c}\text { "There must be one } \\
\text { permanent tutorial room } \\
\text { that is conducive for } \\
\text { learning" -(TR-P5) }\end{array}$ \\
\hline $\begin{array}{c}\text { Conduct a retooling or } \\
\text { skills training for tutors }\end{array}$ & Typical & $\begin{array}{c}\text { "Tutors need to attend } \\
\text { seminars and workshops on } \\
\text { how to be an effective tutor" } \\
\text {-(TE-P8) }\end{array}$ \\
\hline
\end{tabular}

\section{Conduct a college-wide campaign about the program}

To increase student participation and strengthen the programs' goal and advocacy of helping the STARs, the College through the DySAS may conduct a college-wide campaign to promote and raise awareness about the initiative and how students can benefit from it. Organizers may do a room-to-room campaign to reach students and encourage them to get involved.

Teachers can also help in the dissemination effort by introducing the said program - its design, purpose, and benefits during the class orientation. Further, an attractive advertisement may be placed in a conspicuous place within the College area so students will be reminded. Participant 3 made a point by saying, 
"The College should promote the program so that many students would be aware of it and can participate" - (TR-P3)

\section{Provide tutorial materials and resources}

Learning materials and handouts must be provided to tutees. These tools could facilitate a better understanding of the topic being discussed and help students follow through the lessons gained even beyond the tutorial session, hence inspire self-directed, independent learning. Materials also respond equitably to multiple intelligences. It is essential for visual learners and supports auditory and kinesthetic learners as well. In support of this call, Participant 15 detailed,

"Provide learning materials like sample questionnaires and reviewers" (TE-P15)

\section{Offer a flexible schedule or tutorial-time option}

With the different free time and availability of the tutors and tutees, it would be helpful and encouraging to students if they can choose their schedule when to attend the tutorial. Through this, they can thoroughly focus and lend quality time to the activity for effective learning and engagement. They need not hurry nor worry about possible conflict with their regular classes.

This mechanism also serves the interest of the tutors as they will be afforded enough time to prepare themselves, their tools and strategies, so to ensure quality discussion and learning experience for their tutees. Since tutors work within their means and time, they can facilitate better without worry and prejudice to personal academic pursuits. After all, their services are free. This suggestion was held by Participant 10 expressing,

"Posting of flexible schedules for the tutorial session should be made clearly and ahead of time" -(TE-P10)

\section{Conduct a one-on-one tutorial session}

When the crowd of tutees becomes bigger with multiple levels of readiness, conditions, and motivations, it would be very challenging, if not nearly impossible, for tutors to cater all the needs and preferences of the tutees. Tutors can only apply general approaches in discussing the topic. This truth can have different effects, though. For those fast learners, they may get bored; those less prepared may find the discussion harder to follow. Some may get distracted and become disengaged because of class size, while others tend to feel anxious and uncomfortable. All these translate into ineffective learning.

One alternative to group tutoring is one-on-one tutorial session. This alternative addresses the issue of individual learning style, need, and pace. Personal tutorial provides a more comprehensive, well-thought, and customized learning activities. Participant 11 candidly shared his insight on this matter by saying,

"There must be one-on-one tutorial session or buddy-buddy system especially for working students" -(TE-P11) 


\section{Provide a tutorial facility or room}

Having a room for the activity and having a place that fits the learning session are two different yet equally important things. First, there must be a specific room or facility to hold tutorial classes. Second, it must be conducive for learning and can facilitate various teaching strategies available to tutors. The facility must be equipped with learning tools and materials, is accessible, wellventilated, and away from unnecessary disturbances like noise. In support of this need, Participant 5 proposed,

"There must be one permanent tutorial room that is conducive for learning" -(TR-P5)

\section{Conduct a retooling or skills training for tutors}

Akin to the saying, "One cannot give what he or she does not have," tutors need to undergo a regular and structured retooling or training program designed to equip them with the right skills and attitude on teaching and how to manage tutorial sessions. In this way, they can transfer their knowledge to the tutees more effectively.

Just like full-pledged teachers, tutors must be trained about pedagogy and teaching strategies and get oriented about the dos and don'ts of advising and motivating learners. With tutorial sessions, the most challenging part is not about what knowledge and information to share but how to effectively and meaningfully transfer them despite the differing learning styles, intelligence, attitudes, and readiness of the learners. After all, learning is not just about the learner; it is also about the conduits - the teacher and the technology. Participant 8 expressed her hopes that,

"Tutors need to attend seminars and workshops on how to be an effective tutor" -(TE-P8)

\section{Discussion}

This section of the paper presents the discussion on the themes that emerged from the meaningful responses of our participants relative to the research questions. It is organized into four main categories, namely: Perceptions of 'Students at Risk' on the Peer Tutorial Program, Problems Encountered by Students in the Peer Tutorial Program, Benefits of the Peer Tutorial Program to Tutees and Tutors, and Suggestions to Improve the Peer Tutorial Program.

\section{Perceptions of "Students at Risk" on the Peer Tutorial Program}

The Peer Tutorial Program empowers students to appraise and evaluate their academic preparedness, strengths, and weaknesses concerning specific courses and topics (Braganza et al., 2014; O'Dea \& Harris, 2019). It does not only help tutees enhance their understanding and knowledge about a particular lesson or course (Shenoy \& Petersen, 2019) but also promote the spirit of service, sacrifice, teamwork and disciple between and among tutees and tutors (Braganza et al., 2014; Briggs, 2013).

By its worth, the tutorial session is a great help for students, especially those who are struggling to understand their accounting lessons (Shenoy \& Petersen, 2019). At least, through the program, students are able to clarify and deepen 
their understanding of their lessons and can give due attention to addressing specific and personal academic concerns (Bailey, 2010; Aclo et al., 2015; Matinde, 2019). Tutors use varied teaching strategies depending on the topic to be discussed, the time available, and the number of tutees in attendance (Bailey, 2010; Chi \& Vanlehn, 2010). The rule of the thumb, though, is to ensure a friendly, open, comfortable, and inspiring approach, so tutees never get bored, and quality learning is achieved (Aclo et al., 2015; Briggs, 2013).

Tutors are great motivators and serve as an inspiration to tutees. Apart from imparting their knowledge, time, and self, they motivate the tutees to develop self-confidence and continue pursuing their dream of becoming a CPA. They model hope and inspiration to students to carry on despite the hardships and struggles they come across with the accounting course (Aclo et al., 2015; Pratiwi \& Ariani, 2020). In several cases, the tutor-tutee relationship has bloomed into a profound connection of friendship and fellowship (Kram \& Isabella, 1985; Zapata, 2020).

Akin to a classroom, it employs similar teaching techniques commonly used by teachers inside the classroom; thus, tutees can easily follow the dynamics and format of instruction and are more relaxed and open in grasping the lessons (Aclo et al., 2015; Johnson, 2011). Among the popular techniques used were lecture, think-pair-share (TPS), team learning, and debates, among others (Bailey, 2010; Chi \& Vanlehn, 2010).

Essentially, DySAS tutorial program provides meaningful services to students by creating a practical and fun learning experience. It encourages and inspires tutees to continue pursuing their dream of becoming an accounting professional despite the hardships encountered in their core courses. Through DySAS, the tutees have found hope and comfort in their studies and became more driven to study harder (Aclo et al., 2015; Lumactod et al., 2013).

\section{Problems Encountered by Students in the Peer Tutorial Program}

One pressing issue of peer tutorial is student resignation and lowliness. Some students who may feel less and inferior when tutored by fellow students may develop a hostile relationship with one another (Booth \& Hyland, 1996). If a student cultivates this feeling of lowliness, he or she may withdraw from working effectively with his or her assigned peer and, as a result, failing to get the full benefits of the program.

In the context of study participants, the compelling issues and concerns that need to be addressed are the scarcity of learning materials and tools, tutor's poor pedagogy and methodology, lack of infrastructure, conflicting time and schedule between tutors and tutees and the inimical attitude of the learners towards the program. In the works of Jain (2010), it was held that little had been reported about the efficacy of peer tutorials on improving the class performance of tutees. He even argued that the risk of transferring the wrong knowledge from one student to another brought about by inexperienced and incompetent tutors could bring more harm than help to participants (Pratiwi \& Ariani, 2020). 


\section{Benefits of Peer Tutorial Program to Tutees and Tutors}

The peer tutorial, as cited by Chi et al. (2008), is an effective academic program that encourages learners to become active participants in the learning process through tutoring and collaborating with peers. In tutorials, tutees and tutors become partners by allowing each other discover their strengths and weaknesses and, together, help improve those areas that require enhancement (Astin, Wogelgesang, Ikeda \& Yee, 2000). While the tutees learn from their tutors, the tutors master the lessons. Falchicov (2001) described collaborative learning to be instrumental in developing self-esteem, improving academic performance (Viana et al., 2019), creating new friends, increasing course interest, and improving study habits.

The Athletic Study Center (2016) asserted that tutorial is an alternative learning technique that promotes and enhances a student's academic competencies and self-resolve (Topping, 2005; Colvin \& Ashman, 2010). In the same light, tutorials foster students' self-reliance and self-confidence as they get engaged in academics. Students learning with fellow students eliminate that feeling of intimidation, inhibition, and reservations; thus, it is easy for them to clarify and qualify knowledge without fear of being ridiculed or feeling undignified (Aclo et al., 2015; Dowd, 2018).

On another thought, Palfreyman and Tapper (2013) accentuated that peer tutoring allows students to ask questions and clarifications, which seldom happens in the classroom. It should be noted, however, that peer tutoring complements and is not replacing classroom instruction (Briggs, 2014; Zapata, 2020). Tutoring is not and will never be displacing professional teaching. In fact, blending these two learning modalities, bringing its strengths, can be a powerful means to helping STARs improve their academic pursuits. As Borchert (2000) and Debard (2004) put it, millennial students learn quickly and effectively when with others. They are more team-oriented than individualistic (Dowd, 2018; Johnson \& Johnson, 2009).

In their study, Kunch, Jitendra, and Sood (2007) discussed that peer tutoring is best when students of diverse abilities and intelligence toil together in teams to learn specific material or practice an academic task. Progress happens when an experienced student, usually a senior, helps a novice learner enhance his or her skills and knowledge (Dowd, 2018). Along this process, a tutor's personal growth as he or she imparts learning and provides support to the mentee (Colvin \& Ashman, 2010; Osborne \& Othman, 2019). Likewise, Alakija (2005) stressed that a good relationship between tutors and tutees is essential in tutorials because tutoring improves not just knowledge but also character and values.

\section{Suggestions to Improve the Peer Tutorial Program}

While the University of Mindanao embraces continuing quality improvement (CQI) as an approach to grow and advance its management systems, so is the College of Accounting Education in developing innovative and improved programs and activities for its stakeholders, especially the students (Pratiwi \& Ariani, 2020). Through this approach, the College could identify the weak areas 
and can exhaust means to perfect it, making it more current, relevant, and effective for the students and other interested parties (O'Dea \& Harris, 2019).

The tutorial program is not an exemption to this approach. From the design to the implementation of the program, there have been many areas that require further enhancement. Suggested improvements had been as simple as awareness campaign and provision of learning materials to more complex and resourceintensive like the conduct of retooling (Osborne \& Othman, 2019) and construction of the tutorial facility, among others. As an output of this study, an action plan was developed. The action plan encloses the detailed set of activities that can be done to ensure quality, effective, and sustainable tutorial program for both tutees and tutors.

\section{Conclusion}

Peer tutorial may be a timeworn, alternative means to collaborative learning but it has proven to be effective and powerful in helping not just those having difficulty in their academics and non-performing in their courses, but also those who want to enrich their knowledge, skills and even character by teaching fellow students. It works in two ways: tutees get to understand, clarify and learn more about the lessons, and tutors get the chance to contribute to the success of their colleagues and find purpose and satisfaction from studying to remain credible and competent in imparting knowledge. Inspired by the University's vocation, "No one is left behind," the College's peer tutorial program envisions a conscientious alternative education where students help their fellow students improve their academic readiness and performance during exams and classroom activities, all in the spirit of inclusive excellence and responsible community. It is on this truth that the College acknowledges the significant role played by students to improve the quality and delivery of equitable education. It may still be a long way for the Institution to perfect this Peer Tutorial Program but what is worth celebrating now is the partnership that is built between the College and its students as well as the trust afforded by the College towards its studenttutors in helping the 'STAR' achieve their academic outcomes. While this study is delimited on assessing the implementation of the Program, significant lessons and insights can be drawn for future investigation as to its sustainability and implication to education policy. Nonetheless, we still applaud the gallantry and solidarity developed and shown by the tutors towards their fellows. This is teamwork that works. This is excellence in citizenship at its best.

\section{References}

Aclo, K. M., Damiar, J., \& Norodin, A. (2015). Looking Through the Eyes of the Learners: A Qualitative Assessment on DySAS Tutorial Program (Thesis). University of Mindanao, Philippines.

Alakija, S. (2005). Getting into Oxford and Cambridge. London: Trotman \& Co Ltd.

Albrecht, W. S. \& Sack, R. J. (2001). The Perilous Future of Accounting Education. The CPA Journal, 71(3), 16.

Astin, A. W., Vogelgesang, L., Ikeda, E. K., \& Yee, J. A. (2000). How Service learning affects students. Los Angeles: Higher Education Research Institute, University of California. Retrieved from https://www. gseis. ucla/edu/slc 
Athletic Study Center (2016). Tutorial Program Handbook Policies \& Procedures, Spring 2016. University of California, Berkeley. Retrieved from https://bcourses.berkeley.edu/files/64948331/download?download_frd=1

Bailey, G. (2010). Tutoring Strategies: A Case Study Comparing Learning Center Tutors and Academic Department Tutors. The University of North Carolina, Greensboro, USA.

Bloom, B. (1984). The 2 Sigma Problem: The Search for Methods of Group Instruction as Effective as One-on-One Tutoring. Educational Researcher, 13(6), 4-16. doi:10.3102/0013189x013006004

Booth, A., \& Hyland, P. (Eds.). (1996). History in Higher Education. Oxford: WileyBlackwell.

Borchert, D. (2000). Book Review: Millennials Rising: The Next Great Generation. Review \& Expositor, 97(3), 392-393. doi:10.1177/003463730009700318

Braganza, M. P., Capisnon, E., Dela Salde, S., \& Manib, N. (2014). DySAS Peer Tutorial Program: Its Impact to the Exam Results of the Tutees (Thesis). University of Mindanao, Philippines.

Briggs, S. (2013). How Peer Teaching Improves Student Learning and 10 Ways to Encourage it. Retrieved from https://www.opencolleges.edu.au/informed/features/peerteaching/

Briggs, S. (2014). 25 Things Skilled Learners Do Differently. Retrieved from https://www.opencolleges.edu.au/informed/features/25-things-skilledlearners-do-differently/

Chen, C., \& Liu, C. C. (2011). A Case Study of Peer Tutoring Program in Higher Education. Research in Higher Education Journal, 11(1), 16-34. Retrieved from https://www.aabri.com/manuscripts/11757.pdf

Chi, M., Roy, M., \& Hausmann, R. (2008). Observing Tutorial Dialogues Collaboratively: Insights about Human Tutoring Effectiveness from Vicarious Learning. Cognitive Science: A Multidisciplinary Journal, 32(2), 31-41. doi:10.1080/03640210701863396

Chi, M., \& Vanlehn, K. (2010). Meta-Cognitive Strategy Instruction in Intelligent Tutoring Systems: How, When, and Why. Educational Technology \& Society, 13(1), 25-39.

Colvin, J. W., \& Ashman, M. (2010). Roles, Risks, and Benefits of Peer Mentoring Relationships in Higher Education. Mentoring \& Tutoring: Partnership in Learning, 18(2), 121-134. doi:10.1080/13611261003678879

Creswell, J. W. (1998). Qualitative Inquiry \& Research Design: Choosing Among Five Traditions. Thousand Oaks: CA. Sage Publications, Inc. Retrieved from https:// psycnet.apa.org/record/1997-36445-000

DeBard, R. (2004). Millennials coming to College. New Directions for Student Services, 3345. doi:10.1002/ss.123

Dowd, M. (2018). What Are Some Advantages and Disadvantages of Peer Tutoring? Retrieved from https://classroom.synonym.com/advantages-disadvantages-peertutoring-8385009.html

Dynamic Society of Accounting Students [DySAS] (2015). Summative Report on Tutorial Program: 1st Semester Academic Year 2015-2016. College of Accounting Education, University of Mindanao, Philippines.

Exley, K., \& Dennick, R. (2004). Small Group Teaching. Tutorials, Seminars and Beyond. London: Routledge. doi:10.4324/9780203465066

Falchicov, N. (2001). Learning Together: Peer Tutoring in Higher Education. London: Routledge. doi:10.4324/9780203451496 
Flores, M. A., Veiga Simao, A. M., \& Carrasco, V. (2012). Tutoring in Higher Education in Portugal and Spain: Lessons Learned from Six Initiatives in Place. Internationalizing Education: Global Perspectives on Collaboration and Change (pp. 107-124).

Hannes, K., Booth, A., Harris, J., \& Noyes, J. (2013). Celebrating methodological challenges and changes: reflecting on the emergence and importance of the role of qualitative evidence in Cochrane reviews. Systematic Reviews, 2(1). doi:10.1186/2046-4053-2-84

Jain, A. (2010). Students' Perceptions of Workshop Based Introductory Macroeconomics Tutorials: A Survey. Economic Papers: A journal of applied economics and policy, 25(3), 235-251. doi:10.1111/j.1759-3441.2006.tb00398.x.

Johnson, K. P. (2011). Participatory Formative Assessment: Involving Students in Their Learning. Texas Study of Secondary Education, 22(1). Retrieved from https://www.researchgate.net/profile/Jo_Jimerson/publication/266136755_Do es_Data_Use_Work/links/5425964d0cf238c6ea741f9d.pdf\#page $=5$

Johnson, D. W., \& Johnson, R.T. (2009). An Educational Psychology Success Story: Social Interdependence Theory and Cooperative Learning. Educational Researcher, 38(5), 365-379. doi:10.3102/0013189x09339057

King, N. (2007). Phenomenological Psychology: Theory, Research and Method. Qualitative Research in Organizations and Management: An International Journal, 2(2), 161-163. doi:10.1108/17465640710778548

Kram, K. E., \& Isabella, L.A. (1985). Mentoring Alternatives: The Role of Peer Relationships in Career Development. Academy of Management Journal, 28(1), 110132. doi: $10.5465 / 256064$

Kunsch, C. A., Jitendra, A. K., \& Sood, S. (2007). The Effects of Peer-Mediated Instruction in Mathematics for Students with Learning Problems: A Research Synthesis. Learning Disabilities Research \& Practice, 22(1), 1-12. doi:10.1111/j.15405826.2007.00226.x

Lumactod, C. M., Nipales, K., Pelenio, R., \& Taripe, I. (2013). A Home Found in DySAS: Tutorial Service beyond its Purpose (Thesis). University of Mindanao, Philippines.

Marshall, C., \& Rossman, G.B. (2010). Designing Qualitative Research. (6 ${ }^{\text {th }}$ Edition). Thousand Oaks, CA: Sage.

Matinde, E. (2019). Students' Perceptions on Reciprocal Peer Tutorial Assessment in an Undergraduate Course in Process Metallurgy. Education Sciences, 9(1), 27. doi:10.3390/educsci9010027

O'Dea, M., \& Harris, J. (2019). Effectiveness of Reflective Practice in a Ta PeerMentorship Program. Proceedings of the Canadian Engineering Education Association (CEEA), Ontario, Canada. doi:10.24908/pceea.vi0.13719

Osborne, K., \& Othman, M. (2019). Peer-assisted learning model to support students success in a complex science course. Journal of Nursing Education and Practice, 9(11), 53. doi:10.5430/jnep.v9n11p53

Palfreyman, D., \& Tapper, T. (2013). Oxford and the Decline of the Collegiate Tradition. London: Routledge. doi:10.4324/9780203041253

Pratiwi, B., \& Ariani, D. (2020). The use of hypermedia for Indonesian language learning in distance education. In U. Kusmawan, S. Aisyah, I. Rokhiyah, Andayani, D. R. Jovanka \& D. Sukmayadi (Eds.), Emerging Perspectives and Trends in Innovative Technology for Quality Education 4.0. 1st International Conference on Innovation in Education and Pedagogy (ICIEP 2019), October 5, 2019, Jakarta, Indonesia (pp. 210214). doi:10.1201/9780429289989-60

Shenoy, A., \& Petersen, K. H. (2019). Peer Tutoring in Preclinical Medical Education: A Review of the Literature. Medical Science Educator, 30(1), 537-544. doi:10.1007/s40670-019-00895-y 
Shenton, A. K. (2004). Strategies for Ensuring Trustworthiness in Qualitative Research Projects. Education for Information, 22(2), 63-75. doi:10.3233/EFI-2004-22201.

Silverman, D. (2015). Interpreting Qualitative Data. Great Britain: Sage Publications Ltd.

Topping, K. J. (2005). Trends in Peer Learning. Educational Psychology, 25(6), 631-645. doi:10.1080/01443410500345172

Viana, R. B., Campos, M. H., Santos, D. de A. T., Xavier, I. C. M., Vancini, R. L., Andrade, M. S., \& de Lira, C. A. B. (2018). Improving Academic Performance of Sport and Exercise Science Undergraduate Students in Gross Anatomy Using a Near-Peer Teaching Program. Anatomical Sciences Education, 12(1), 74-81. doi:10.1002/ase.1790

Walby, K. (2015). Marshall, Catherine, and Gretchen B. Rossman, Designing Qualitative Research, Sixth Edition. Canadian Journal of Sociology, 40(3), 399-402. doi:10.29173/cjs25398

Yazedjian, A., \& Kolkhorst, BB (2007). Implementing Small Group Activities in Large Lecture Classes. College Teaching, 55(4), 164-169. doi:10.3200/ctch.55.4.164-169

Zapata, S. (2020). Perceptions of Peer Tutoring at a University in Chile. Magis, Revista Internacional de Investigación En Educación, 12(25), 21-38. doi:10.11144/javeriana.m12-25.pptu 